\title{
Quantitative assessment of heavy metal effects on sperm function using computer-aided sperm analysis and cytotoxicity assays
}

\author{
Farren Hardneck, Gadieja Israel, Edmund Pool and Liana Maree
}

\begin{abstract}
One known environmental risk factor impacting on human reproduction is heavy metal pollution. Although some metals (e.g., $\mathrm{Cu}$, Se and $\mathrm{Zn}$ ) have protective effects on the male reproductive system in low doses, heavy metals can accumulate to toxic levels and result in poor semen quality and decreased sperm function. We investigated the effect of $\mathrm{CuSO}_{4}$ and $\mathrm{CdCl}_{2}(10,50,100$ and $250 \mu \mathrm{g} / \mathrm{ml}$ or $500 \mu \mathrm{g} / \mathrm{ml}$ ) on human sperm motility and vitality by using computer-aided sperm analysis (CASA) and two cytotoxicity assays (WST-1 and XTT). Several sperm motility parameters were significantly reduced after $5 \mathrm{hr}$ of exposure to the highest concentrations of $\mathrm{CuSO}_{4}(250 \mu \mathrm{g} / \mathrm{ml})$ and $\mathrm{CdCl}_{2}(500 \mu \mathrm{g} / \mathrm{ml})$. The WST-1 assay also revealed significantly lower absorbance values for 50,100 and $250 \mu \mathrm{g} / \mathrm{ml} \mathrm{CuSO} 4$ and for 500 $\mu \mathrm{g} / \mathrm{ml} \mathrm{CdCl} 2$; however, no significant effect was seen with XTT. The calculated average IC50 value was $50.31 \pm 4.34 \mu \mathrm{g} / \mathrm{ml}$ for $\mathrm{CuSO}_{4}$ and $392.32 \pm 76.79 \mu \mathrm{g} / \mathrm{ml}$ for CdCl2. The effects of these metals were confirmed with $\mathrm{MgCl} 2$, a positive control. This study provides threshold concentrations for the harmful effect of $\mathrm{CuSO}_{4}$ and $\mathrm{CdCl}_{2}$ on human spermatozoa and recommends the use of WST-1 as vitality assay in future in vitro studies.
\end{abstract}

\section{1 | Introduction}

Male fertility has deteriorated over the past few decades with male factor infertility being accountable for $40 \%-50 \%$ of human infertility (Brugh \& Lipshultz, 2004; Kumar \& Singh, 2015). This decline in semen quality is assumed to have a direct relation with environmental conditions rather than pre-existing factors (Maartens, Aboua, \& du Plessis, 2015) and therefore should be taken into account when assessing male infertility (Mukhopadhyay, Varghese, Nandi, Banerjee, \& Bhattacharyya, 2010).

Environmental risk factors impacting on human reproduction mainly originate from land and water resources that have been subjected to maximum exploitation and severely degraded or polluted due to anthropogenic activities (Lone, He, Stoffella, \& X-e, 2008). Pollution includes both point sources such as emission, vehicle exhaustion and metals from smelting and mining, and nonpoint sources such as soluble salts (natural and artificial), insecticides and pesticides, disposal of industrial and municipal wastes in agriculture, and excessive use of fertilisers (Lone et al., 2008; Maartens et al., 2015). Each source of contamination has its own damaging effects to plants, animals and human health, with those 
adding heavy metals to soils and waters being a serious concern due to its persistence in the environment (Lone et al., 2008). People are exposed to heavy metals either voluntarily through supplementation or involuntarily through the intake of contaminated food and water or contact with contaminated soil, dust or air (Meeker \& Rossano, 2008). Aquatic heavy metal pollution usually represents high levels of $\mathrm{Hg}, \mathrm{Cr}, \mathrm{Pb}, \mathrm{Cd}, \mathrm{Cu}, \mathrm{Zn}$ and $\mathrm{Ni}$ in the water system (Zhou, Zhang, Fu, Shi, \& Jiang, 2008).

Although heavy metals such as $\mathrm{Mn}, \mathrm{Cu}, \mathrm{Cr}, \mathrm{Mb}$, Se and $\mathrm{Zn}$ are important for maintaining good health by serving as cofactors for numerous enzymes, these metals can accumulate to toxic concentrations that may be harmful to humans (Adejuwon, Ilesanmi, \& Akindade, 1996; Yuyan, Junqing, Wei, Weijin, \& Ersheng, 2008). Occupational as well environmental exposure to metals such as $\mathrm{Pb}, \mathrm{Cd}, \mathrm{Cr}$, $\mathrm{Co}$, Ni and As may pose both short-term and long-term health risks (Zhou et al., 2016) and has been divided mainly into carcinogenic and noncarcinogenic effects (Wang, Sato, Xing, \& Tao, 2005). Low doses of metals such as $\mathrm{Cu}$, Se and $\mathrm{Zn}$ have protective effects on the male reproductive system and may assist in counteracting the effects of other metals (Meeker \& Rossano, 2008). However, several of these heavy metals (e.g., $\mathrm{Pb}$ and $\mathrm{Cd}$ ) are considered reproductive toxicants and endocrine disruptor compounds (Mendiola et al., 2011) due to causing hypothalamic-pituitary axis disruption or by its direct affect on Sertoli cells, Leydig cells and spermatogenesis, ultimately resulting in poor semen quality (Chowdhury, 2009; Mendiola et al., 2011; Pizent, Tariba, \& Zivkovic, 2012).

Significant decreases in total sperm count in epididymal samples or sperm concentration in semen have been reported when mice, rats and humans were exposed to Cd (Akinloye, Arowojolu, Shittu, \& Anetor, 2006; Hew, Ericson, \& Welsh, 1993), Pb (Fatima et al., 2010), $\mathrm{Hg}$ (Choy et al., 2002) and As (Chiou, Chu, Tzeng, Huang, \& Liao, 2008) respectively. Additionally, these studies as well as in a study on fish sperm exposed to $\mathrm{Hg}$ (Abascal, Cosson, \& Fauvel, 2007) found a decrease in the percentage normal sperm morphology. Both in vitro exposure of water buffalo sperm to copper sulphate (Tabassomi \& Alavi-Shoushtari, 2013) and subcutaneous injections of arsenic trioxide in mice (Chiou et al., 2008) caused a decrease in sperm viability. All the above-mentioned studies reported a significant decrease in total sperm motility or the percentage progressive swimming spermatozoa (Abascal et al., 2007; Akinloye et al., 2006; Chiou et al., 2008; Choy et al., 2002; Fatima et al., 2010; Hew et al., 1993; Tabassomi \& Alavi-Shoushtari, 2013).

Numerous studies have underlined the importance of sperm motility evaluation, in particular forward or progressive motility, in order to define fertilising capacity, to evaluate the effects of medical and/or surgical treatments and to study the follow-up of kinematic parameters in subjects affected by andrological pathologies (Björndahl, 2010; Elia et al., 2010; van der Horst, Maree, \& du Plessis, 2018). Computer-aided sperm analysis (CASA) is a useful tool for analysing the effects of heavy metals on sperm motility parameters (Dietrich et al., 2010; Mukhopadhyay et al., 2010). CASA not only provides a fast and objective tool for assessing sperm quality, but also allows for the detection of subtle changes in sperm motion that cannot be identified by conventional, manual sperm motility analysis 
(Rijsselaere et al., 2005; van der Horst et al., 2018). This permits the detailed analysis of sperm kinematics and sperm motility subpopulations, especially to indicate possible effects of different environmental conditions on male fertility (Abascal et al., 2007; Maree \& van der Horst, 2013; Mortimer \& Mortimer, 2013; Mortimer, van der Horst, \& Mortimer, 2015).

Sperm vitality is usually assessed by manual or CASA evaluation of the sperm plasma membrane integrity after staining with eosin-nigrosin (dye exclusion test) or fluorescent probes (Sybr-14 or Hoechst and propidium iodide) (van der Horst \& du Plessis, 2017; WHO, 2010). However, since the harmful effect of heavy metals on spermatozoa is due to its interference with the cell's proteins and enzymes (Chowdhury, 2009; Sharma, Goloubinoff, \& Christen, 2008), it should be useful to assess sperm vitality using tests for enzyme function, and thus indirectly a cell's viability, such as the WST-1 and XTT cytotoxicity assays. These assays measure the cleavage of tetrazolium salts by active enzymes (mitochondrial dehydrogenases), producing a formazan dye detectable only in metabolic active cells (Roche Diagnostics, 2006, 2011).

The objective of this study was to determine the effect of various concentrations of heavy metals (cadmium chloride and copper sulphate) on human sperm motility and vitality by utilising CASA and two cytotoxicity assays (WST-1 and XTT). Additionally, we aimed to identify which sperm functional test can be used to calculate $\mathrm{IC}_{50}$ values for the two mentioned heavy metals.

\section{2 | Materials and methods}

\section{1 | Samplecollection and evaluation}

Thirteen normospermic human semen samples were acquired from seven healthy donors by masturbation, after two to three days of sexual abstinence, as part of a donor programme (Division of Physiology, Department of Biomedical Sciences, Stellenbosch University). To be considered for use, semen samples were selected according to the following WHO criteria: semen volume $\geq 1.5 \mathrm{ml}$, sperm concentration $\geq 15 \times 10^{6} / \mathrm{ml}$, total motile sperm $\geq 40 \%$ and a $\mathrm{pH}$ range of 7.2-8.0 (WHO, 2010). After collection, semen samples were kept at $37^{\circ} \mathrm{C}$ for $30-60$ min in order for liquefaction to occur before semen was processed. Ethical clearance for this study was obtained from the Ethics Committees of the University of the Western Cape (Ref. no. 13/10/90) and Stellenbosch University (Ref. no. N14/06/074). The Helsinki Declaration governing research on humans has been adhered to (Christie, 2000) and each human donor gave written consent.

\subsection{Selection of motile spermatozoa}

Human tubal fluid (HTF) (Mortimer, 1994) was used as medium for all experimental procedures. HTF was supplemented with $1 \%$ human serum albumin (HSA). All chemicals were supplied by Sigma, Cape Town, South Africa.

A double density gradient centrifugation technique was employed to select motile spermatozoa by using PureSperm (Kat Medical Laboratories, Johannesburg, South Africa). 
This procedure involved layering $400 \mu \mathrm{l}$ PureSperm 80 into a $1.7 \mathrm{ml}$ conical centrifuge tube, followed by $400 \mu \mathrm{l}$ PureSperm 40 and finally adding $400 \mu$ liquefied semen onto the PureSperm 40. The preparation was centrifuged at $300 \mathrm{~g}$ for $20 \mathrm{~min}$, followed by removal of the supernatant. The sperm pellet was then washed by resuspending it in $200 \mu$ HTF (without HSA) and centrifugation at $500 \mathrm{~g}$ for $10 \mathrm{~min}$, followed by removal of the supernatant. The remaining pellet was resuspended in $100 \mu \mathrm{l} \mathrm{HTF}$ (with HSA), with or without a specific metal concentration, to result in a final concentration of $10-20 \times 10^{6} / \mathrm{ml}$ motile spermatozoa.

\section{3 $\mid$ Exposure of spermatozoa to heavy metals}

Sperm preparations were exposed to different concentrations of the two specified heavy metals, namely copper sulphate $\left(\mathrm{CuSO}_{4}\right)$ and cadmium chloride $\left(\mathrm{CdCl}_{2}\right)$. Initially, a dose-response was used to determine which metal concentrations to expose the spermatozoa to (data not shown). The final concentrations selected were 10, 50, 100 and 250 $\mu \mathrm{g} / \mathrm{ml}$ for $\mathrm{CuSO}_{4}$ and $10,50,100$ and $500 \mu \mathrm{g} / \mathrm{ml}$ for $\mathrm{CdCl}_{2}$ respectively. Similar concentrations of magnesium chloride $\left(\mathrm{MgCl}_{2}\right)$ were used as positive control. All metal concentrations were prepared using HTF supplemented with $1 \%$ HSA.

Motile sperm preparations were exposed to these metal concentrations for up to $5 \mathrm{hr}$ while being incubated at $37^{\circ} \mathrm{C}$. The sperm motility and vitality of the prepared samples were assessed every hour for $5 \mathrm{hr}$, as it was shown by Roblero, Guadarrama, Lopez, and Zegers-Hochschild (1996) that sperm motility, vitality and acrosome reaction were significantly affected by $100 \mu \mathrm{g} / \mathrm{ml}$ copper ion $\left(\mathrm{Cu}^{2+}\right)$ after $5 \mathrm{hr}$ of incubation. All experiments were done in triplicate $(n=3)$ with three different donors' samples used for each experiment.

\section{4 | Sperm motility analysis}

Sperm motility was assessed after $15 \mathrm{~min}$ and then after 1, 2, 3, 4 and $5 \mathrm{hr}$ of incubation using the Motility module of the Sperm Class Analyzer $®$ (SCA) (Microptic S.L., Barcelona, Spain) CASA system, Version 5.1. Capturing of the data involved a Basler avA 1,000-100gc digital camera (Microptic S.L., Barcelona, Spain) that was mounted on an Olympus $\mathrm{CH} 2$ microscope (Wirsam, Cape Town, South Africa), equipped with a $10 \times$ phase contrast objective and a heated stage.

Sperm motility analysis involved pipetting $2-3 \mu \mathrm{l}$ of sperm preparation into $20 \mu \mathrm{m}$ deep prewarmed $\left(37^{\circ} \mathrm{C}\right)$ four or eight chamber Leja slides (Leja Products B.V., Nieuw-Vennep, The Netherlands). The percentages total motility, progressive motility, rapid, medium and slow swimming spermatozoa and eight kinematic parameters were analysed by capturing sperm tracks at 40 frames/s until a total of 200 motile spermatozoa were analysed. The kinematic parameters included curvilinear velocity (VCL), straight-line velocity (VSL), average path velocity (VAP), amplitude of lateral head displacement (ALH), linearity (LIN=VSL/VCL), straightness $(\mathrm{STR}=\mathrm{VSL} / \mathrm{VAP}$ ), wobble (WOB $=\mathrm{VAP} / \mathrm{VCL}$ ) and beat-cross frequency $(\mathrm{BCF})$. The three sperm subpopulations were determined using VCL cut-off values of $22<60>90$ 
$\mu \mathrm{m} / \mathrm{s}$ to identify slow, medium and rapid swimming spermatozoa (Maree \& van der Horst, 2013). Fields were captured randomly to eliminate bias towards higher sperm motility; however, fields containing debris or clumps of spermatozoa were avoided to limit incorrect analysis.

\subsection{Sperm vitality analysis}

Sperm vitality was assessed using two colorimetric assays, namely XTT (sodium 2,3-bis(2-methoxy-4-nitro-5-sulfophenyl)-5-[(phenylamino)-carbonyl]-2H-tetrazolium inner salt; Cell Proliferation Kit II; Cat. No. 11465015 001) and WST-1 (sodium 5-(2,4-disulfophenyl)-2-(4-iodophenyl)-3-(4-nitrophenyl)-2Htetrazoliuminner salt; Cell Proliferation Agent; Cat No. 11644807 001), which is commonly used it tissue culture studies for cell proliferation, viability and cytotoxicity assessments (Roche, Mannheim, Germany).

The WST-1 labelling reagent was prepared according to the manufacturer's protocol by mixing $200 \mu \mathrm{l}$ WST-1 reagent with $800 \mu \mathrm{l}$ phosphate-buffered saline (PBS). The XTT labelling reagent was prepared by mixing $1 \mathrm{ml}$ XTT reagent with $20 \mu \mathrm{l}$ PMS electron-coupling reagent. For both assays, $50 \mu \mathrm{l}$ sperm preparation and $50 \mu \mathrm{l}$ labelling reagent were added to the wells of a microtitre plate in duplicate for each metal concentration. A zero-minute reading was obtained where after plates were incubated at $37^{\circ} \mathrm{C}$ and $5 \% \mathrm{CO}_{2}$ until the next analysis. Measurements of the absorbance were taken after 1, 2, 3, 4 and $5 \mathrm{hr}$ of incubation using an ELISA reader (Microplate reader, Multiskan EX, Thermo Scientific) set at 450 $\mathrm{nm}$ with a reference wavelength of $650 \mathrm{~nm}$.

Using these absorbance measurements, $\mathrm{IC}_{50}$ values, defined as the concentrations of the heavy metals required for $50 \%$ inhibition of sperm vitality, were determined as a parameter for the toxicity of $\mathrm{CuSO}_{4}$ and $\mathrm{CdCl}_{2}$

\section{6 | Statistical analysis}

MedCalc $\AA$ version 10.4.0.0 (Mariakerke, Belgium) was used for basic statistical analyses. Levene's test for equality of variances was applied and when $p>0.05$, one-way analysis of variance analysis (ANOVA) was performed for parametric data distributions. Any significant differences $(p<0.05)$ as indicated in the ANOVA table between groups were furthermore analysed using the Student-Newman-Keuls test for pairwise comparisons. In subsets of data that appeared to have nonparametric data distributions, the Kruskal-Wallis test was employed and further elaborated for individual differences using the Mann-Whitney test for independent samples. Data are represented as the mean $\pm \mathrm{SD}$ in figures and $p<0.05$ was considered significant using the analyses above.

\section{Results}

Exposure of motile human spermatozoa $(n=3)$ to different concentrations of $\mathrm{CuSO}_{4}$ and $\mathrm{CdCl}_{2}$ had a negative impact on several motility parameters over the 5 -hr incubation period. However, significant decreases $(p<0.05)$ were only found at the highest concentration of 
$\mathrm{CuSO}_{4}(250 \mu \mathrm{g} / \mathrm{ml})$ and $\mathrm{CdCl}_{2}(500 \mu \mathrm{g} / \mathrm{ml})$. After $2 \mathrm{hr}$ of $\mathrm{CuSO}_{4}$ exposure, percentage progressive motility, sperm velocity (VSL and VAP) and linearity (LIN) started to decrease and after $3 \mathrm{hr}$ of incubation, percentage total motility and VCL also showed significantly lower values (Figure 1a-c). The three swimming speed classes (rapid, medium and slow sperm) and other kinematic parameters were not significantly affected by $\mathrm{CuSO}_{4}$ exposure. For $\mathrm{CdCl}_{2}$ exposure, similar results were found in terms of decreased motility parameters for $\mathrm{CuSO}_{4}$ exposure (Figure 1d-f). Interestingly, these decreases were already apparent after only $15 \mathrm{~min}$ to $\mathrm{I}$ hr of incubation.
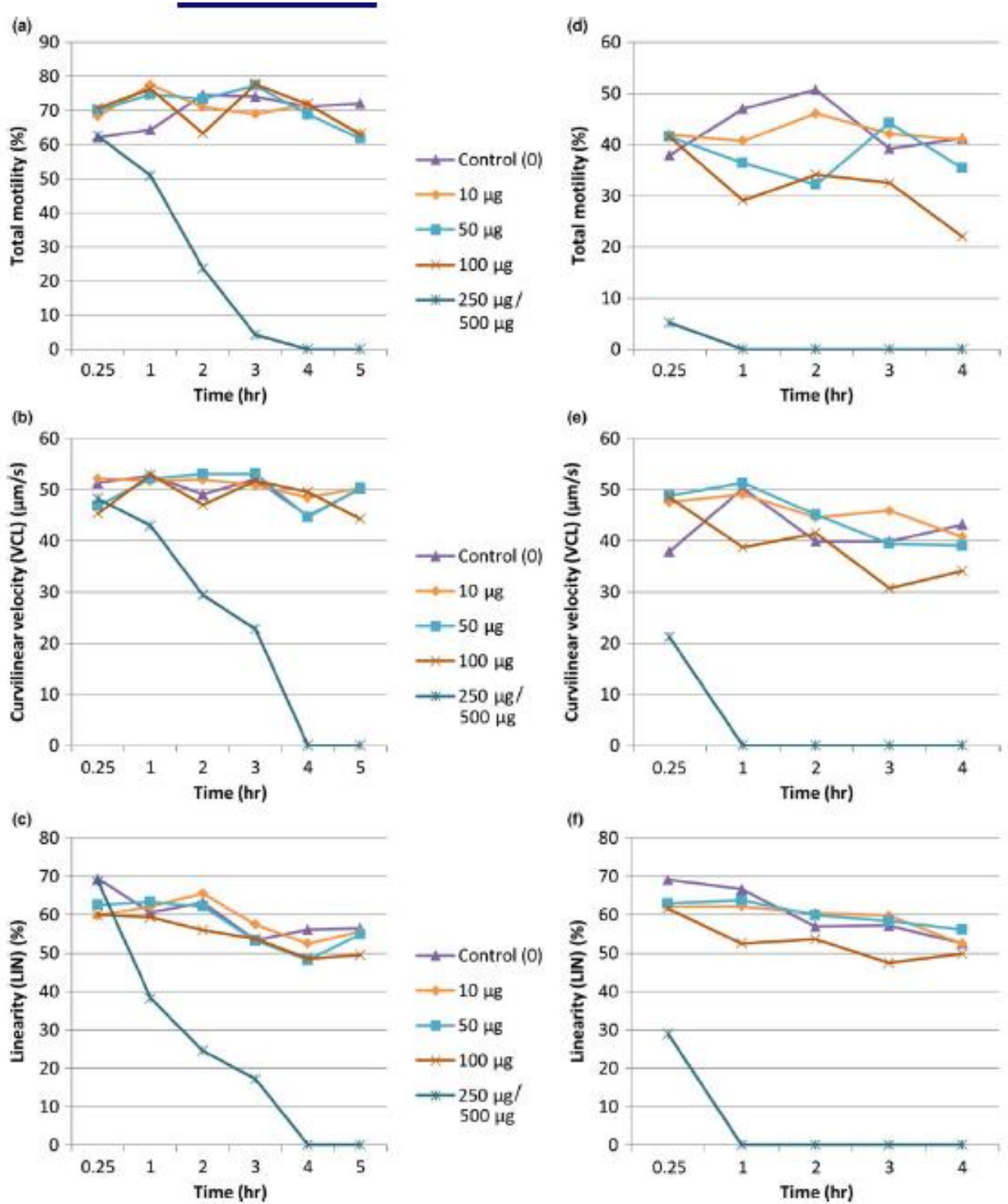

FIGURE 1 Examples of the effect of various concentrations of $\mathrm{CuSO}_{4}(0-250 \mu \mathrm{g} / \mathrm{ml})$ and $\mathrm{CdCl}_{2}(0-500 \mu \mathrm{g} / \mathrm{ml})$ on sperm motility parameters after $4-5 \mathrm{hr}$ of incubation, including $(a, d)$ total motility, $(b, e)$ curvilinear velocity and $(c, f)$ linearity. Each graph represents the data for one donor exposed to these heavy metal concentrations 
The effect of the two heavy metals on sperm vitality was assessed by using the XTT and WST-1 cytotoxicity assays $(n=3)$. After both $\mathrm{CuSO}_{4}$ and $\mathrm{CdCl}_{2}$ exposure, there was no significant effect on vitality when only XTT results were considered (Figure $2 \mathrm{a}$ and c). On the other hand, WST-1 results revealed significantly lower average absorbance values for 50, 100 and $250 \mu \mathrm{g} / \mathrm{ml} \mathrm{CuSO}_{4}$ after $4 \mathrm{hr}$ of incubation (Figure 2a). Although the WST-1 average absorbance (0.23) at $500 \mu \mathrm{g} / \mathrm{ml} \mathrm{CdCl}_{2}$ after $5 \mathrm{hr}$ of incubation (Figure 2c) was $56 \%$ less than the control (0.53), this decrease was not significant $(p=0.12)$. Significantly lower absorbance values were, however, found in verification experiments (see Figure $3 \mathrm{~d}$ ). Due to the XTT assay not revealing any effect of the two heavy metals on sperm vitality, $\mathrm{IC}_{50}$ values were calculated using only WST-1 average absorbance values. The average $\mathrm{IC}_{50}$ value for $\mathrm{CuSO}_{4}$ was $50.31 \pm 4.34 \mu \mathrm{g} / \mathrm{ml}$ and for $\mathrm{CdCl}_{2}$, it was $392.32 \pm 76.79 \mu \mathrm{g} / \mathrm{ml}$. Examples of the calculation of $\mathrm{IC}_{50}$ values for individual donor samples are indicated in Figure $2 \mathrm{~b}$ $\left(\mathrm{CuSO}_{4}\right)$ and Figure $2 \mathrm{~d}\left(\mathrm{CdCl}_{2}\right)$.

In order to verify the negative effect of $\mathrm{CuSO}_{4}$ and $\mathrm{CdCl}_{2}$ on sperm motility and vitality, a third mineral salt, namely $\mathrm{MgCl}_{2}$, was used as positive control to compare its effect on these sperm functional parameters. On its own, similar concentrations (10,50, 250, 500 $\mu \mathrm{g} / \mathrm{ml}$ ) of $\mathrm{MgCl}_{2}$ had no significant effect on sperm motility or vitality over a 5 -hr incubation period (Figure 3). A significant decrease in percentage total sperm motility and WST-1 absorbance, compared to the control and $\mathrm{MgCl}_{2}$, was observed after $5 \mathrm{hr}$ of incubation when motile sperm was exposed to $250 \mu \mathrm{g} / \mathrm{ml} \mathrm{CuSO}_{4}$ (Figure 3a,b). Similar significant decreases in sperm motility and WST-1 absorbance were also found for motile sperm exposed to $500 \mu \mathrm{g} / \mathrm{ml} \mathrm{CdCl}_{2}$

\section{4 | Discussion}

In this study, the negative effect of both heavy metals was illustrated by a significant decrease in percentage total motility and progressive motility as well as VCL, VSL, VAP and LIN. These CASA-derived sperm velocity parameters have been shown to be closely related to fertility prediction and pregnancy outcomes in humans (Shibahara et al., 2004) and animals (Ahmed, Andrabi, Anwar, \& Jahan, 2017; Nagy, Polichronopoulos, Gáspárdy, Solti, \& Cseh, 2015). A decrease in these parameters could thus be a contributing factor to male infertility.

Our results corroborate the findings of previous studies, reporting reductions in sperm motility and sperm velocity parameters after exposure to $\mathrm{Cd}$ or $\mathrm{Cu}$ in humans (Mukhopadhyay et al., 2010), rabbit (Roychoudhury \& Massanyi, 2008), turkey (Slanina, Miškeje, Petrovičová, Lukáč, \& Massányi, 2015), common carp (Chyb, Sokolowska-Mikolajczyk, Kime, Socha, \& Epler, 2001) and African catfish (Kime, Ebrahimi, Nysten, Roelants, \& Ollevier, 1996). Mukhopadhyay et al. (2010) found a significant decline in VCL and STR in a tobacco-exposed group, whereas a heavy metal-exposed group had a significant reduced VCL and ALH. High concentrations of Cu in 
seminal plasma are also correlated with reduced sperm motility and may render sperm immotile (Roblero et al., 1996; Wong et al., 2001). Aberrant sperm motility caused by heavy metals such $\mathrm{a} \mathrm{Pb}$ and $\mathrm{Cd}$ is correlated with altered expression of L-type voltage-dependent calcium channel isoforms found on the sperm tail, which regulate calcium influx required for flagellar bending (Benoff, Auborn, Marmar, \& Hurley, 2008).

FIGURE 2 Effect of various concentrations of $(a, b) \mathrm{CuSO}_{4}(0-250 \mu \mathrm{g} /$ $\mathrm{ml}$ and 5-hr incubation) and (c,d) $\mathrm{CdCl}_{2}$ $(0-500 \mu \mathrm{g} / \mathrm{ml}$ and 4 -hr incubation) on sperm vitality $(n=3)$. IC $C_{50}$ values for $\mathrm{CuSO}_{4}$ (b) and $\mathrm{CdCl}_{2}$ (d) for individual donors were calculated using only WST-1 average absorbance values ${ }^{*} p<0.05$ (a)

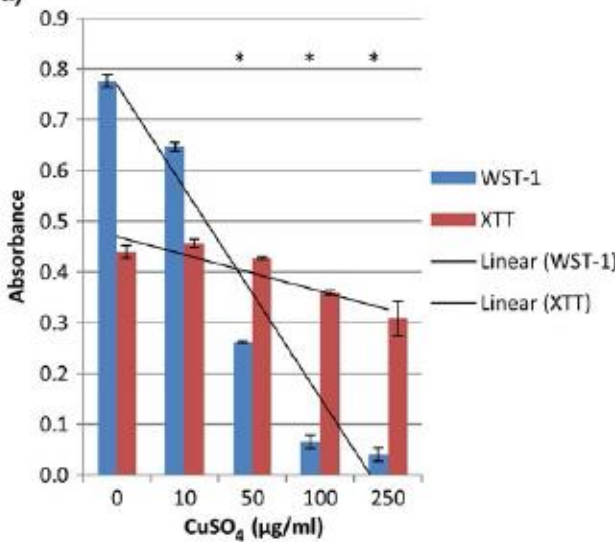

(b)

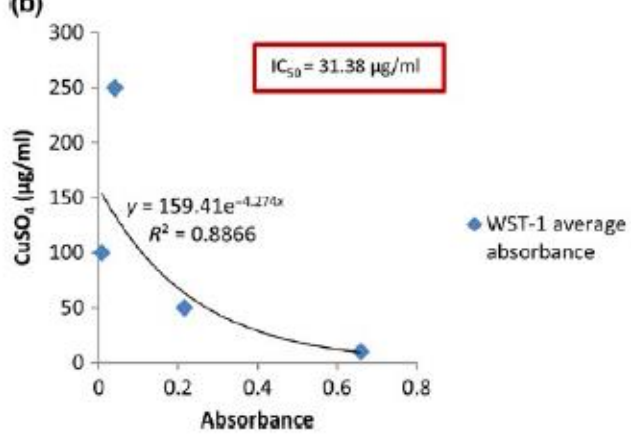

(c)

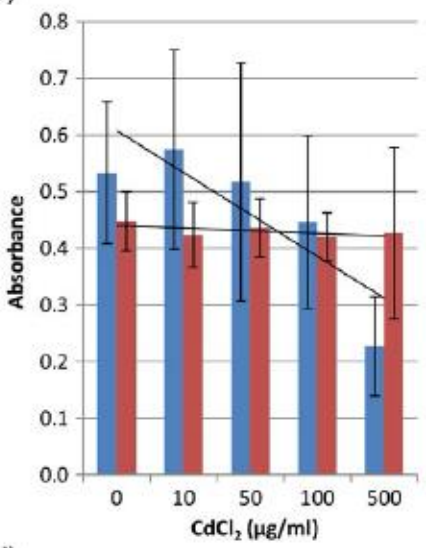

(d)

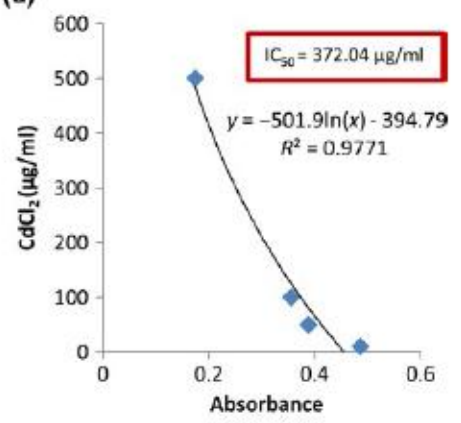


(a)

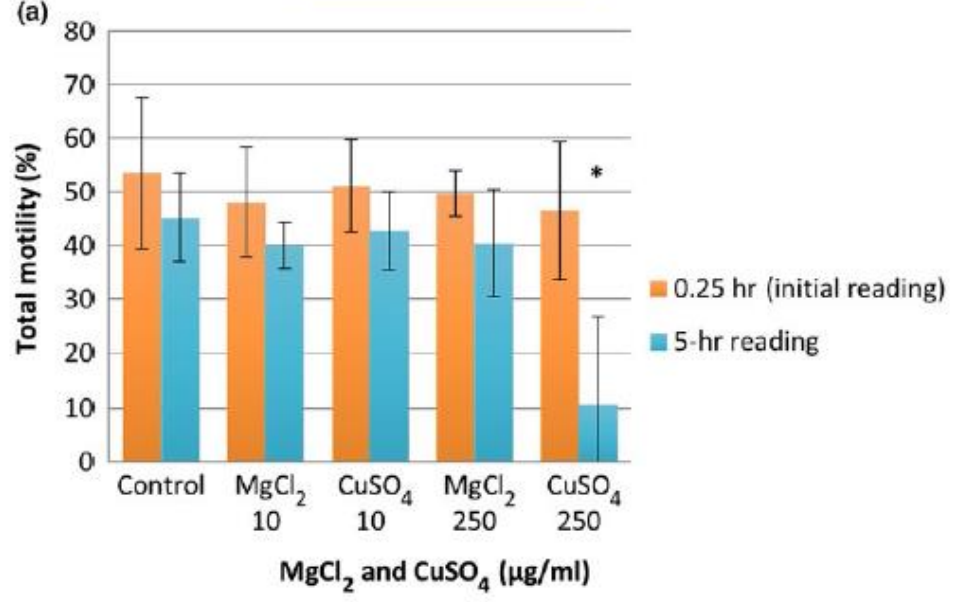

(b)

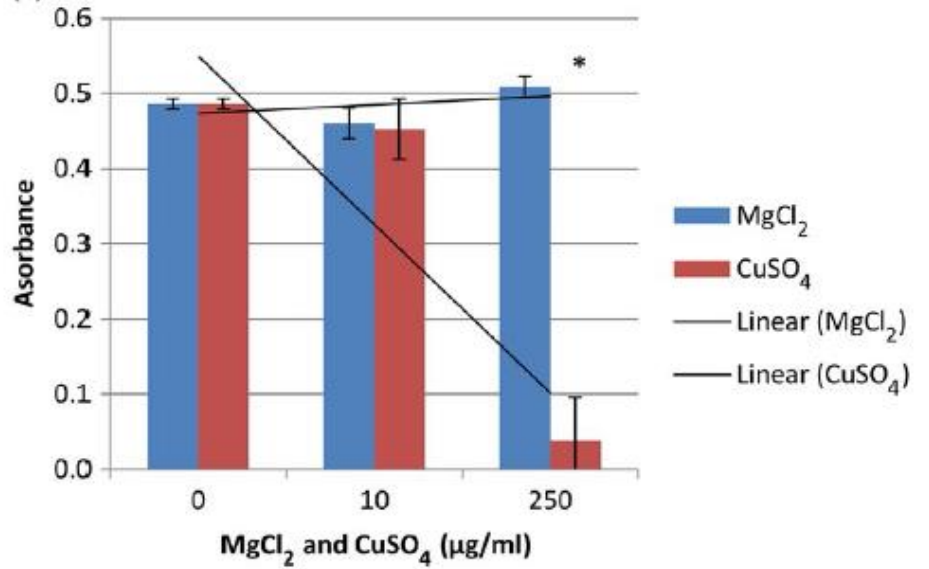

(c)

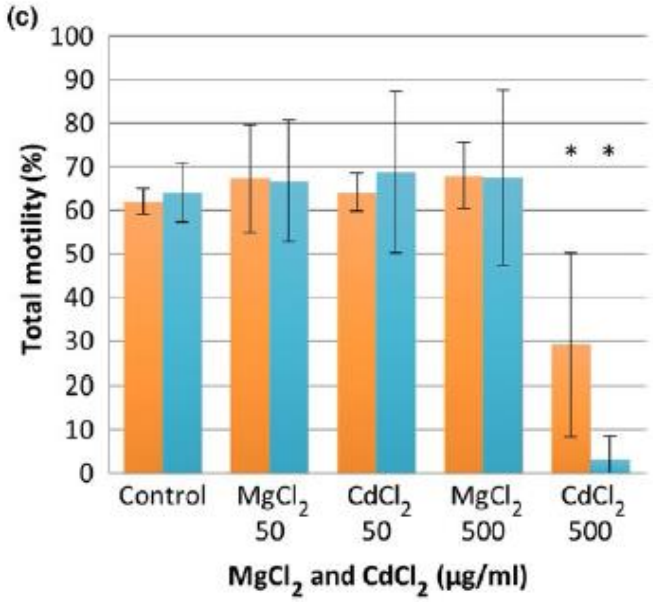

(d)

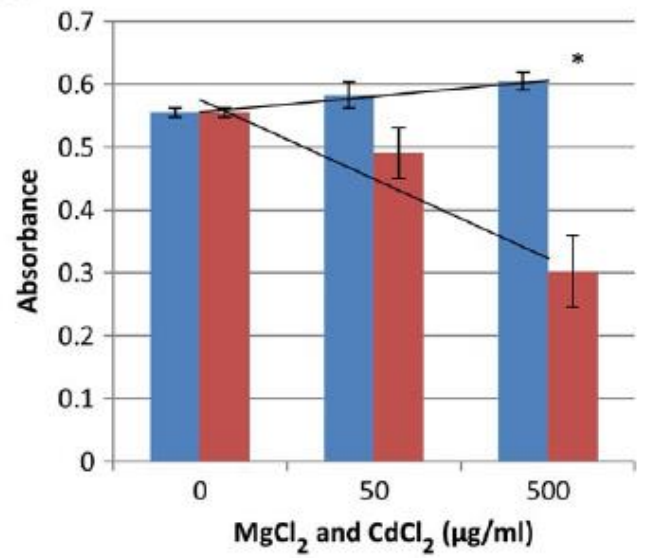

FIGURE 3 Comparison of the effect of similar concentrations of $\mathrm{MgCl}_{2}$ to $(a, b) \mathrm{CuSO}_{4}$ and $(\mathrm{c}, \mathrm{d}) \mathrm{CdCl}_{2}$ on percentage total motility $(\mathrm{a}, \mathrm{c})$ and WST-1 reduction (b,d) after 15 min and $5 \mathrm{hr}$ of incubation. ${ }^{*} p<0.05$

Our in vitro study only revealed significant negative effects on sperm motility and vitality at the highest concentration of $\mathrm{CuSO}_{4}(250 \mu \mathrm{g} / \mathrm{ml})$ and $\mathrm{CdCl} 2(500 \mu \mathrm{g} / \mathrm{ml})$ selected for exposure. There are, however, species differences in the concentration of these heavy metals that will result in deleterious effect on spermatozoa. Additionally, in vivo and longer duration studies indicated a severely negative effect on sperm parameters at much lower heavy metal concentrations than reported here. An in vivo study by Benoff et al. (2008) demonstrated a dose-dependent decrease in sperm motility of rats after exposure to 5 or 50 $\mu \mathrm{g} / \mathrm{ml}$ cadmium in drinking water for four weeks.

Interestingly, the adverse effect of $\mathrm{CdCl}_{2}$ on sperm motility in our study was already seen within $1 \mathrm{hr}$ of exposure, while for $\mathrm{CuSO}_{4}$, an evidential decrease was only seen after $2-3 \mathrm{hr}$. Similar results were reported for Holstein bulls where $\mathrm{CdCl}_{2}$ was reported to decrease sperm motility with increasing Cd concentrations $(20-700 \mu \mathrm{mol})$ after $60 \mathrm{~min}$ (Arabi, 2006). Tabassomi and Alavi-Shoushtari (2013) also indicated a significant decrease in water buffalo sperm motility percentages after $60-120 \mathrm{~min}$ of exposure to $0.064 \mu \mathrm{g} / \mathrm{ml} \mathrm{CuSO}_{4}$. It is possible that the concentration of $\mathrm{CdCl}_{2}$ used in our study was too high, and it thus had an almost immediate shock effect on sperm motility. However, 
sperm vitality was only significantly reduced at $500 \mu \mathrm{g} / \mathrm{ml} \mathrm{CdCl}{ }_{2}$. Alternatively, this almost instant effect of $\mathrm{CdCl}_{2}$ can be explained by the fact that $\mathrm{Cd}$ is highly toxic for mammalian cells (Telišman et al., 2000). Copper on the other hand occurs naturally, is an essential trace element and plays a vital part of several enzymes, such as ferroxidases, cytochrome c oxidase and superoxide dismutase (Slanina et al., 2015; Van Niekerk \& Van Niekerk, 1989).

Since heavy metals often interfere with the structure and function of proteins and enzymes (Chowdhury, 2009; Sharma et al., 2008), its adverse effects should be easily detected by assessing changes in metabolic activity. Likewise, Telišman et al. (2000) found better correlations with reproductive parameters when enzymatic activity (biomarker for $\mathrm{Pb}$ exposure) rather than blood and seminal fluid levels of $\mathrm{Pb}$ was used to assess its effect on reproductive function. In the current study, a significant decrease in WST-1 average

absorbance values was seen for 50,100 and $250 \mu \mathrm{g} / \mathrm{ml} \mathrm{CuSO}_{4}$ after $4 \mathrm{hr}$ of incubation and for $500 \mu \mathrm{g} / \mathrm{ml} \mathrm{CdCl}_{2}$ after $5 \mathrm{hr}$ of incubation. The XTT assay, however, did not detect significant effects of these two heavy metals on sperm vitality and thus proved to be less sensitive than the WST-1 assay. Aitken, Ryan, Curry, and Baker (2003) also indicated that human spermatozoa have the ability to reduce the WST-1 reagent, and this significant effect was seen after $2 \mathrm{hr}$ of incubation. The advantages of WST-1 are that it is more stable and more sensitive than MTT-, XTT- or MTS-based assays (Abcam plc (1998-2017; Berridge, Herst, \& Tan, 2005) and WST-1 also has a wider linear range and shows accelerated colour development compared to XTT (Roche Diagnostics, 2006). Comparing the WST-1 results with the motility results in our study, it also seems that the WST-1 assay is more sensitive to detect the adverse effects of at least $\mathrm{CuSO}_{4}$ on sperm function.

Previous studies reported similar decreases in absorbance values and sperm vitality when spermatozoa were exposed to various $\mathrm{Cu}$ and $\mathrm{Cd}$ concentrations. Buffalo spermatozoa exposed to $3.9-1,000 \mu \mathrm{mol} / \mathrm{l} \mathrm{Cu}$ resulted in a significant decrease in sperm motility and viability (MTT assay) at all concentrations of $\mathrm{Cu}$ (Knazicka, Tydra, Bardos, \& Lukac, 2012). Several earlier studies found that seminal plasma Cd levels (Dawson, Ritter, Harris, Evans, \& Powell, 1998) and cigarette smoking were inversely correlated with the percentage live sperm (Chia, Xu, Ong, Tsakok, \& Lee, 1994; Emad, Azza, Sohair, Nagwa, \& Taymour, 2012). Copper and cadmium toxicities lead to ROS production and oxidative stress (Liu et al., 2010), followed by DNA, protein and lipid oxidation (Kaur \& Sharma, 2015; Olivari, Hernandez, \& Allende, 2008), which are negatively correlated with sperm motility and viability (Tvdra et al., 2013). Any excess of $\mathrm{Cu}$ in a cell is reduced to cuprous ions that readily bind with sulfhydryl groups (Vlarengo, Pertica, Mancinelli, Zanicchi, \& Orunesy, 1980), interfering with electron transport and inhibiting ATP production (Wimalasena, Wiese, \& Wimalasena, 2007). Sharma et al. (2008) proved that $\mathrm{Cd}, \mathrm{Hg}$ and $\mathrm{Pb}$ affect spontaneous and chaperone-assisted folding of proteins by forming multidendate complexes with thiol, imidazole and carboxyl groups, which are all present in several intracellular enzymes. 
With the WST-1 assay being more sensitive than XTT in revealing any effect of the two heavy metals, the $\mathrm{IC}_{50}$ values were calculated using the average absorbances from the WST-1 assay. The average $\mathrm{IC}_{50}$ value for $\mathrm{CuSO}_{4}$ and $\mathrm{CdCl}_{2}$ in this study was calculated to be $50.31 \mu \mathrm{g} / \mathrm{ml}$ and $392.32 \mu \mathrm{g} / \mathrm{ml}$ respectively. Knazicka et al. (2012) found that buffalo sperm viability, via MTT assay, was decreased significantly after copper administration $(3.9,7.8,15.6,31.2,62.5,125,250,500,1,000 \mu \mathrm{mol} / \mathrm{l})$. The concentrations $250 \mu \mathrm{mol} / \mathrm{l}$ and $500 \mu \mathrm{mol} / \mathrm{l} \mathrm{Cu}^{2+}$ are equivalent to $37.96 \mu \mathrm{g} / \mathrm{ml}$ and $75.53 \mu \mathrm{g} / \mathrm{ml}$, which places our $\mathrm{IC}_{50}$ value of $50.31 \mu \mathrm{g} / \mathrm{ml} \mathrm{CuSO}_{4}$ within this range. Arabi (2006) found that concentrations of 100-700 $\mu \mathrm{mol} \mathrm{CdCl}_{2}$ significantly lowered Holstein bull sperm viability after $60 \mathrm{~min}$ of incubation. The $700 \mu \mathrm{mol} / \mathrm{l}$ concentration is equivalent to $105.74 \mu \mathrm{g} / \mathrm{ml} \mathrm{CdCl} 2$, which is far less than the calculated $\mathrm{IC}_{50}$ value obtained from the current study.

We used $\mathrm{MgCl}_{2}$ as a positive control since a previous study reported that $\mathrm{MgCl}_{2}$ significantly improved the velocity of paddlefish spermatozoa (Linhart, Cosson, Mims, Shelton, \& Rodina, 2002). However, as $\mathrm{MgCl}_{2}$ had no significant effect on human sperm motility and vitality, it might be a suitable heavy metal control for future studies. Magnesium is an important cation found in nearly all enzymatic systems and is a vital cofactor in more than 300 enzymatic reactions involving energy metabolism (ATP) and nucleic acid synthesis (Wong et al., 2001).

\section{5 | Conclusion}

Albeit many previous studies have investigated the effect of heavy metals on spermatozoa, it is important to note that the effect of each heavy metal is species specific and dependent on route of administration, dosage and duration. Our findings provide threshold concentrations for the harmful effect of $\mathrm{CuSO}_{4}$ and $\mathrm{CdCl}_{2}$ on human spermatozoa for use in future in vitro studies or as bioindicator for heavy metal toxicity. We recommend the use of WST-1 assays rather that XTT assays for evaluation of human sperm vitality. Future studies on these heavy metals should include the evaluation of additional sperm functional parameters such as acrosome reaction, DNA integrity, hyperactivation, cervical-mucus penetration and zona pellucida binding.

\section{Acknowledgements}

The authors express their gratitude to Prof Stefan du Plessis and postgraduate students (Reproductive Research Laboratory, Division of Medical Physiology, Department of Biomedical Sciences, Stellenbosch University) for their assistance with acquiring donor semen samples. Dr Kim Lategan is thanked for her assistance with cytotoxicity assays and data interpretation. This study was supported by funding from the National Research Foundation (NRF).

\section{ORCID}

Liana Maree http://orcid.org/oooo-00o3-4147-4221 


\section{References}

Abascal, F. J., Cosson, J., \& Fauvel, C. (2007). Characterization of sperm motility in sea bass: The effect of heavy metals and physicochemical variables on sperm motility. Journal of Fish Biology, 70, 509-522. https://doi.org/10.1111/j.1095-8649.2007.01322.x

Abcam plc. (1998-2017). WST-1 Assay Reagent - Cell Proliferation (ready to use) (ab155902), Product Datasheet. Retrieved from https://www. abcam.com/wst-1-assay-reagent-cell-proliferation-ready-to-use-ab155902-reference s.html, 1-2.

Adejuwon, C. A., Ilesanmi, A. O., \& Akindade, K. S. (1996). Biophysical and biochemical analysis of semen in infertile Nigerian men. African Journal of Medicine and Sciences, 25, 217-219.

Ahmed, H., Andrabi, S. M., Anwar, M., \& Jahan, S. (2017). Use of post-thaw semen quality parameters to predict fertility of water buffalo (Bubalus bubalis) bull during peak breeding season. Andrologia, 49, e12639.

Aitken, R. J., Ryan, A. L., Curry, B. J., \& Baker, M. A. (2003). Multiple forms of redox activity in populations of human spermatozoa. Molecular Human Reproduction, 9, 645661. https://doi.org/10.1093/molehr/ gago86

Akinloye, O., Arowojolu, A. O., Shittu, O. B., \& Anetor, J. I. (2006). Cadmium toxicity: A possible cause of male infertility in Nigeria. Reproductive Biology, 6, 17-30.

Arabi, M. (2006). Cadmium as an etiology of sperm dysfunction in Holstein bulls. Iran $J$ of Vet Res, 7, 29-36.

Benoff, S., Auborn, K., Marmar, J. L., \& Hurley, I. R. (2008). Link between low-dose environmentally relevant cadmium exposures and asthenozoospermia in a rat model. Fertility and Sterility, 89, 73-79. https:// doi.org/10.1016/j.fertnstert.2007.12.035

Berridge, M. V., Herst, P. M., \& Tan, A. S. (2005). Tetrazolium dyes as tools in biology: New insights into their cellular reduction. Biotechnology Annual Review, 11, 127-152.

Björndahl, L. (2010). The usefulness and significance of assessing rapidly progressive spermatozoa. Asian Journal of Andrology, 12, 33-35. https://doi.org/10.1038/aja.2008.50

Brugh, V. M., \& Lipshultz, L. I. (2004). Male factor infertility: Evaluation and management. Medical Clinics of North America, 88, 367-385. https://doi.org/10.1016/Soo25-7125(03)00150-o

Chia, S. E., Xu, B., Ong, C. N., Tsakok, F. M., \& Lee, S. T. (1994). Effect of cadmium and cigarette smoking on human semen quality. International Journal of Fertility and Menopausal Studies, 39, 292-298.

Chiou, T. J., Chu, S. T., Tzeng, W. F., Huang, Y. C., \& Liao, C. J. (2008). Arsenic trioxide impairs spermatogenesis via reducing gene expression levels in testosterone synthesis pathway. Chemical Research in Toxicology, 21, 1562-1569. https://doi.org/10.1021/tx700366x

Chowdhury, A. R. (2009). Recent Advances in Heavy Metals induced effect on male reproductive function - a retrospective. Al Ameen Journal of Medical Science, 2, $37-42$. 
Choy, C. M. Y., Lam, C. W. K., Cheung, L. T. F., Briton-Jones, C. M., Cheung, L. P., \& Haines, C. J. (2002). Infertility, blood mercury concentrations and dietary seafood consumption: A case-control study. BjogAn International Journal of Obstetrics and Gynaecology, 109, 1121-1125.

Christie, B. (2000). Doctors revise declaration of Helsinki. BMJ, 321, 913. Chyb, J., Sokolowska-Mikolajczyk, M., Kime, D. E., Socha, M., \& Epler, P. (2001). Computer-assisted analysis (CASA) of common carp Cyprinus Carpio L. spermatozoa motility in the presence of cadmium. Archives of Polish Fisheries, 9, 173-181.

Dawson, E. B., Ritter, S., Harris, W. A., Evans, D. R., \& Powell, L. C. (1998). Comparison of sperm viability with seminal plasma metal levels. Biological Trace Element Research, 64, 215-219. https://doi. org/10.1007/BFo2783337

Dietrich, G. J., Dietrich, M., Kowalski, R. K., Dobosz, S., Karol, H., Demianowicz, W., \& Glogowski, J. (2010). Exposure of rainbow trout milt to mercury and cadmium alters sperm motility parameters and reproductive success. Aquatic Toxicology, 97, 277284. https://doi. org/10.1016/j.aquatox.2009.12.010

Elia, J., Imbrogno, N., Delfino, M., Mazzilli, R., Rossi, T., \& Mazzilli, F. (2010). The importance of the sperm motility classes - future directions. Open Andrology Journal, 2, 42-43.

Emad, A. T., Azza, M. E., Sohair, K. S., Nagwa, M. G., \& Taymour, M. (2012). Effect of smoking on sperm vitality, DNA integrity, seminal oxidative stress, zinc in fertile men. Urology, 8o, 822-825. https://doi. org/10.1016/j.urology.2012.07.002

Fatima, P., Debnath, B. C., Hossain, M. M., Rahman, D., Banu, J., Begum, S. A., \& Rahman, M. W. (2010). Relationship of blood and semen lead level with semen parameter. Mymensingh Medical Journal, 19, 405-414.

Hew, K. W., Ericson, W. A., \& Welsh, M. J. (1993). A single low cadmium dose causes failure of spermiation in the rat. Toxicology and Applied Pharmacology, 121, 15-21. https://doi.org/10.1006/taap.1993.1123

Kaur, S., \& Sharma, S. (2015). Evaluation of toxic effect of cadmium on sperm count, sprm motility and sperm abnormality in albino mice. International Journal of Advanced Research, 3, 335-343.

Kime, D. E., Ebrahimi, M., Nysten, K., Roelants, I., \& Ollevier, F. (1996). Use of computer assisted sperm analysis (CASA) for monitoring the effects of pollution on sperm quality of fish; application to the effects of heavy metals. Aquatic Toxicology, 36, 223-237. https://doi. org/10.1016/So166-445X(96)oo806-5

Knazicka, Z., Tydra, E., Bardos, L., \& Lukac, N. (2012). Dose and time dependent effect of copper ions on the viability of bull spermatozoa in different media. Journal of Environmental Science and Health Part A Toxic Hazardous Substances and Environmental Engineering, 47, $13294-$ https://doi.org/10.1080/10934529.2012.672135

Kumar, N., \& Singh, A. K. (2015). Trends of male factor infertility, an important cause of infertility: A review of literature. Journal of Human Reproductive Sciences, 8, 191-196. https://doi. org/10.4103/0974-1208.170370 
Linhart, O., Cosson, J., Mims, S. D., Shelton, W. L., \& Rodina, M. (2002). Effects of ions on the motility of fresh and demembranated paddlefish (Polyodon spathula) spermatozoa. Reproduction, 124, 713-719. https://doi.org/10.1530/rep.0.1240713

Liu, R. Z., Gao, J. C., Zhang, H. G., Wang, R. X., Zhang, Z. H., \& Liu, X. Y. (2010). Seminal plasma zinc level may be associated with the effect of cigarette smoking on sperm parameters. Journal of International Medical Research, 38, 923-928. https://doi. org/10.1177/147323001003800318

Lone, M. I., He, Z.-L., Stoffella, P. J., \& X-e, Y. (2008). Phytoremediation of heavy metal polluted soils and water: Progresses and perspectives. Journal of Zhejiang University Science B, 9, 210-220. https://doi. org/10.1631/jzus.Bo710633

Maartens, P. J., Aboua, Y. G., \& du Plessis, S. S. (2015). Role of environmental factors and gonadotoxin exposure in unexplained male infertility. In G. L. Schattman, S. C. Esteves, \& A. Agarwal (Eds.), Unexplained infertility: Pathophysiology, evaluation and treatment. Ch.12 (pp. 121-138). New York: Springer.

Maree, L., \& van der Horst, G. (2013). Quantification and identification of sperm supoulations using computer-aided sperm analysis and species-specific cut-off values for swimming speed. Biotechnic \& Histochemistry, 88, 181-193.

Meeker, J. D., \& Rossano, M. G. (2008). Cadmium, lead, and other metals in relation to semen quality: human evidence for molybdenum as a male reproductive toxicant. Environmental Health Perspectives, 116, 1473-1479. https://doi.org/10.1289/ehp.11490

Mendiola, J., Moreno, J. M., Roca, M., Vergara-Juarez, N., Martinez-Garcia, M. J., Garcia-Sanchez, A., ... Torres-Cantero, A. M. (2011). Relationships between heavy metal concentrations in three different body fluids and male reproductive parameters: A pilot study. Environmental Health Perspectives, 10, 1-7. https://doi. org/10.1186/1476-069X-10-6

Mortimer, D. (1994). Practical Laboratory Andrology. New York: Oxford University Press.

Mortimer, D., \& Mortimer, S. T. (2013). Computer-Aided Sperm Analysis (CASA) of Sperm Motility and Hyperactivation. In D. T. Carrell, \& K. I. Aston (Eds.), Spermatogenesis: Methods and Protocols, Methods in Molecular Biology 927 (pp. 77-87). New York: Springer.

Mortimer, S. T., van der Horst, G., \& Mortimer, D. (2015). The future of computer-aided sperm analysis. Asian Journal of Andrology, 17, 545- 553. https://doi.org/10.4103/1008-682X.154312

Mukhopadhyay, D., Varghese, A. C., Nandi, P., Banerjee, S. K., \& Bhattacharyya, A. K. (2010). CASA-based sperm kinematics of environmental risk factor-exposed human semen samples designated as normozoospermic in conventional analysis. Andrologia, 42, 242-246. https://doi.org/10.1111/j.1439-0272.2009.00984.x

Nagy, Á., Polichronopoulos, T., Gáspárdy, A., Solti, L., \& Cseh, S. (2015). Correlation between bull fertility and sperm cell velocity parameters generated by computer-assisted semen analysis. Acta Veterinaria Hungarica, 63, 370-381. https://doi.org/10.1556/004.2015.035 
Olivari, F. A., Hernandez, P. P., \& Allende, M. L. (2008). Acute copper exposure induces oxidative stress and cell death in lateral line hair cells of zebrafish larvae. Brain Research, 1244, 1-12. https://doi. org/10.1016/j.brainres.2008.09.050

Pizent, A., Tariba, B., \& Zivkovic, T. (2012). Reproductive toxicity of metals in men. Archives of Industrial Hygiene and Toxicology, 1, 35-46. https://doi.org/10.2478/10004-1254-63-2012-2151

Rijsselaere, T., van Soom, A., Tanghe, S., Coryn, M., Maes, D., \& de Kruif, (2005). New techniques for the assessment of canine semen quality: A review. Theriogenology, 64, 706-719. https://doi.org/10.1016/j. theriogenology.2005.05.021

Roblero, L., Guadarrama, A., Lopez, T., \& Zegers-Hochschild, F. (1996). Effect of Cu ion on the motility, viability, acrosome reaction and fertilizing capacity of human spermatozoa in vitro. Reproduction, Fertility, and Development, 8, 871-874.

Roche Diagnostics (2006). Cell Proliferation Reagent WST-1 (pp. 1-4). Mannheim: Roche Diagnostics GmbH, Roche Applied Science.

Roche Diagnostics (2011). Cell Proliferation Kit II (XTT) (pp. 1-4). Mannheim: Roche Diagnostics GmbH, Roche Applied Science.

Roychoudhury, S., \& Massanyi, P. (2008). In vitro copper inhibition of the rabbit spermatozoa motility. Journal of Environmental Science Health Part A Toxic Hazardous Substance and Environmental Engineering, 43, 51-656.

Sharma, S. K., Goloubinoff, P., \& Christen, P. (2008). Heavy metal ions are potent inhibitors of protein folding. Biochemical and Biophysical Research Communications, 372, 341-345. https://doi.org/10.1016/j. bbrc.2008.05.052

Shibahara, H., Obara, H., Ayustawati, H. Y., Suzuki, T., Ohno, A., Takamizawa, S., \& Suzuki, M. (2004). Prediction of pregnancy by intrauterine insemination using CASA estimates and strict criteria in patients with male factor infertility. International Journal of Andrology, 27, 63-68.

Slanina, T., Miškeje, M., Petrovičová, I., Lukáč, N., \& Massányi, P. (2015). Changes In Turkey spermatozoza motility parameters after addition of copper sulphate in vitro. Journal of Microbiology, Biotechnology and Food Sciences, 4, 98-100. https://doi.org/10.15414/ jmbfs.2015.4.special2.98-100

Tabassomi, M., \& Alavi-Shoushtari, S. M. (2013). Effects of in vitro copper sulphate supplementation on the ejaculated sperm characteristics in water buffaloes (Bubalus bubalis). Veterinary Research Forum, 4, 31-36.

Telišman, S., Cvitković, P., Jurasović, J., Pizent, A., Gavella, M., \& Ročić, (2000). Semen quality and reproductive endocrine function in relation to biomarkers of lead, cadmium, zinc, and copper in men. Environmental Health Perspectives, 108, 45-53. https://doi. org/10.1289/ehp.0010845

Tvdra, E., Lukac, N., Schneidgenova, M., Lukacova, J., Szabo, C. S., Goc, Z., ... Massányi, P. (2013). Impact of seminal chemical elements on the oxidative balance in bovine seminal plasma and spermatozoa. Journal of Veterinary Medicine, 2013, 1-8. https://doi. org/10.1155/2013/125096

van der Horst, G., \& du Plessis, S. S. (2017). Not just the marriage of figaro: But the marriage of WHO/ESHRE semen analysis criteria with sperm functionality. Advanced Andrology Online, 4, 6-21. 
van der Horst, G., Maree, L., \& du Plessis, S. S. (2018). Current perspectives of CASA applications in diverse mammalian spermatozoa. Reproduction, Fertility and Development, 3o(6), 875. https://doi. org/10.1071/RD17468.

Van Niekerk, F. E., \& Van Niekerk, C. H. (1989). The influence of experimentally induced copper deficiency on the fertility of rams. I. Semen parameters and peripheral plasma androgen concentration. Journal of the South African Veterinary Association, 6o, 28-31.

Vlarengo, A., Pertica, M., Mancinelli, G., Zanicchi, G., \& Orunesy, M. (1980). Rapid induction of copper-binding proteins in the gills of metal exposed mussels. Comparative Biochemistry and Physiology, 67, 215-218.

Wang, X., Sato, T., Xing, B., \& Tao, S. (2005). Health risks of heavy metals to the general public in Tianjin, China via consumption of vegetables and fish. Science of the Total Environment, 350, 28-37. https://doi. org/10.1016/j.scitotenv.2004.09.044

Wimalasena, D. S., Wiese, T. J., \& Wimalasena, K. (2007). Copper ions disrupt dopamine metabolism via inhibition of V-H+-ATPase: A possible contributing factor to neurotoxicity. Journal of Neurochemistry, 101, 313-326.

Wong, W. Y., Flik, G., Groenen, P. M. W., Swinkels, D. W., Thomas, C. M. G., Copius-Peereboom, J. H. J., ... Steegers-Theunissen, R. P. (2001). The impact of calcium, magnesium, zinc, and copper in blood and seminal plasma on semen parameters in men. Reproductive Toxicology, 15, 131-136. https://doi.org/10.1016/ So890-6238(01)00113-7

World Health Organization (WHO) (2010). WHO laboratory manual for the Examination and processing of human semen. Switzerland: WHO Press.

Yuyan, L., Junqing, W., Wei, Y., Weijin, Z., \& Ersheng, G. (2008). Are serum zinc and copper levels related to semen quality? Fertility and Sterility, 89, 1008-1011. https://doi.org/10.1016/j. fertnstert.2007.04.028

Zhou, H., Yang, Y., Zhou, X., Liu, L., Gu, J., Wang, W., ... Liao, B. (2016). Accumulation of heavy metals in vegetable species planted in contaminated soils and the health risk assessment. International Journal of Environmental Research and Public Health, 13, 289. https://doi. org/10.3390/ijerph13030289

Zhou, Q., Zhang, J., Fu, J., Shi, J., \& Jiang, G. (2008). Biomonitoring: An appealing tool for assessment of metal pollution in the aquatic ecosystem. Analytica Chimica Acta, 606, 135-150. https://doi.org/10.1016/j.aca.2007.11.018 